\title{
Dope, Den gyldne Golden, tyske borgere og engelsk sport. Litteraturorientering
}

\author{
Af Jørn Hansen og Thomas Skovgaard
}

\section{Mфller og Mфldrup - det ny dope, der ikke skal sluges råt}

I 1998 udgaven af Idrætshistorisk Årbog kunne man blandt andet kaste sig over et bidrag med titlen »Sport og Doping - analyse af en aktuel hysteri « forfattet af Verner Møller. Halvvejs gennem året 1999 fik årbogens læsere mulighed for, i styrket form og på mere omfattende vis at repetere mange af denne artikels centrale temaer og gennemgående synspunkter angående brugen af diverse medicinske-kemiske produkter indenfor en lang række af sportens grene - med særlig focus på cykelsporten. Snublende nært på startdatoen for årets landevejsshow show par excellence - Tour De France - udkom af samme forfatter den meget omtalte bog Dopingdjcevelen - analyse af en hed debat.

Debatten om Verner Møllers værk kan i kort udgave summeres til på den ene side anerkendelse af forsøget på en kritisk analyse af den aktuelle dopingdebat, der, hvad angår såvel omfang som skingerhed $i$ toneleje, for alvor accellerede med afsløringerne under Tour De France 1998. På den anden side en markant afstandstagen fra en bog, og dermed for fleres vedkommende ligeledes dennes forfatter, der giver en »interessant, forførende, vanvittig og kynisk manipulerende på grænsen til det uanstændige « analyse af dopingproblematikken, som dagbladet Aktuelt's Søren Gotfredsen skrev.
Verner Møllers bog skabte debat og har dermed tjent sit vigtigste formål, nemlig at fremme en flersidet og forståelsesorienteret debat af doping-feltet. Lad os håbe den konfliktuelle essens af denne med tiden trænger igennem og finder fodfæste blandt den brogede flok af beslutningstagere tilknyttet sportens verden. Under alle omstændigheder har den fundet vej til det udvalg kulturministeriet i februar 1999 satte til at udarbejde en rapport om doping $\mathrm{i}$ Danmark Profilen Doping i Danmark. En hvidbog, som kan rekvireres via enhver boghandel eller hos Statens Information. Uafhængigt af til hvilket brug og formål ministeriets hvidbog og Verner Møllers bidrag til debatten af dopingproblematikken fremover måtte finde anvendelse, kan vi andre glæde os over, at vi er blevet klogere, og skal visdommen yderligere opgraderes på feltet kan det passende ske via en anden af det forgangne års spændende debatessays - Den medicinerede normalitet af farmaceut Claus Møldrup.

Udgivelserne af henholdsvis Møller og Møldrup har mere end én ting tilfælles:

For det første er de begge udgivet som led i en række af debat-bøger fra forlaget Gyldendal. For det andet er de problemstillinger forfatterne i flere omgange har arbejdet med pludseligt kommet voldsomt $\mathrm{i}$ vælten i kølvandet på den intensiverede debat af dopingproblematikken, der igen har stimuleret en noget bredere, men ikke 
destomindre helt central, diskussion af medicinens (i første omgang mest i betydningen medicinske præparaters) funktion og placering i samfund som det danske. For det tredje mener begge forfattere grundlæggende, at debatten af dopingproblematikken er forfejlet og ensidigt fordømmende i særdeleshed overfor de af sportens udøvere, der er direkte involveret heri.

Møllers kritik går på, at det er gået hen over hovedet på de fleste, at (den professionelle) sport er præget af et livssyn og en skala for (livs)kvalitetsvurdering, der på afgørende punkter afviger et godt stykke fra det, vi i mangel af bedre udtryk kan kalde det alment accepterede. Dette er særligt tydeligt på den måde, at sporten ikke så meget trækker på »den etiske fordring « om skelnen mellem ret og vrang, men udpræget er et felt forbundet med æstetikkens interesse for det skønne, hvor det skønne i denne sammenhæng er higen efter overskridelsen af hidtidig egen formåen, konfrontationen med modstanden og endelig sejr uden skelen til moralske overvejelser om det rimelige i det.

Claus Møldrup tager fat et andet sted og spørger, hvorledes vi kan tillade os at fare i flint over eliteidrætsudøveres brug af præstationsfremmende midler samtidig med vi selv - og det i stigende grad - tager medicin for at forstærke vore normale evner, psykiske som fysiske.

Det korte svar er, at sådan har vi - forstået som samfundet - bestemt det skal være. En række autoritativt fastsatte værdisætninger med gyldighed for samfundet danner grænsen mellem det alment rette og rimelige og det alment forkerte og forkastelige. Vægten skal her placeres på begrebet »fastsættelse«, der henviser til en kontinunerlig proces, hvorigennem hele eller dele af det gældende værdisæt for et givet samfund konstant, men med veks- lende hastighed er under de- og rekonstruktion.

I et videre perspektiv er det et spørgsmål om, hvorledes forståelsen og betydningen af begreber som sport, doping, medicin og sundhed ændres og omstruktureres gennem tid og rum, at indsparkene fra Møller og Møldrup bliver yderligere interessante.

Verner Møller mener, at anerkendelsen af (elite)sportens væsensforskellighed fra (bredde)idrætten, samt den langt fra entydige afspejling af »samfundet« i sporten må lede til accept af, at den nødvendige diskussion af og handlen i forhold til eksempelvis doping skal ske på sportens helt særegne præmisser med respekt for dennes autonomi.

Claus Møldrup er derimod rede til at gå langt videre med hensyn til samfundets pligt og ret til direkte kontrol af delfelters (sporten værende et sådant) anvendelse af forhåndenværende muligheder. Dette skal ifølge Møldrup ske med udgangspunkt i en refleksiv stillingtagen til, det han uden videre overvejelser kalder de dybereliggende konsekvenser af sådan noget som et stigende medicinforbrug. Legitimeringen henter han $\mathrm{i}$, at vi alle må og skal inddrages og deltage i udviklingen af en samfundsmæssig fornuftig medicinsk fremtid, der altså også strækker sig ind på sportens domæne. Uden at have det som et udtalt formål tager de to forfattere hermed fat på et tema, der af gode grunde ofte dukker op i diskussioner af den nævnte karakter - nemlig begrebet frihed. Spændingsfeltet indfinder sig her som så mange gange før i vægtningen af den personlige frihed til at skabe sin egen tilværelse kontra samfundets frihed til at strukturere og dermed ofte på én og samme tid både udvide og begrænse individets frihed med henvisning til en eller anden form for hævdvunden eller institutionaliseret legitim begrundelse. 
Dopingproblematikken understreger på særlig vis denne helt grundlæggende nærmest dikotomiske stillingtagen mellem enten at lade et individualistisk eller et kollektivistisk grundsyn råde i sociale sammenhænge.

Den heftige debat af dopingproblematikken har ligeledes givet anledning til at puste nyt liv i en ældgammel diskusison af idrættens og sportens væsen. Det tidligere nævnte hvidbogsudvalg nedsat af kulturministeriet appelerer direkte i sin opsummering idrættens organisationer til at beslutte sig for, hvad en værdifuld aktivitet, der kan betegnes som idræt eller sport, er for noget og skal være i fremtiden. Før det er på plads kan der ikke blive tale om en egentlig tackling af den normalt medicinerede dopingdjævel.

\section{Den gyldne Golden}

I år er det igen blevet tid til verdens største sammenrend af eliteidrætsudøvere - de moderne olympiske sommerlege i Australien. I den anledning skal der peges på en enkelt udgivelse, som på fortræffelig vis beskæftiger sig med fænomenerne de olympiske lege og samfund. Det er dog hverken de moderne udgave af legene eller samfundet, der er sat under lup, men derimod de antikke former, sådan som de menes at have taget sig ud i den klassiske græske oldtid, hvilket vil sige cirka femte og fjerde århundrede før vor tidsregning.

Den anbefalelsesværdige bog Sport and Society in Ancient Greece er skrevet af Mark Golden, professor ved klassiske studier University of Winnipeg. Den vidtfavnende titel er valgt med omtanke, da der er tale om en introduktion. For historikere med særlig interesse i antikken eller blot ældste historiske tid er det ment som en introduktion til sport og idræt. For idrætshi- storikere, der ikke ved meget om den antikke verden, er det omvendt en god mulighed for et kvalificeret blik ind i denne. Med lidt god vilje og standhaftighed kan bogen endog anbefales til den alment interesserede læser.

Golden angiver selv, at bogen er blevet til, fordi der findes overraskende få bøger, som søger at diskutere idrættens og mere generelt fysisk aktivitets og kropslighedens, roller og funktioner i det oldgræske samfund. Gamle travere som E.N Gardiner og H.A. Harris er stadig brugbare, men de skrev trods alt deres hovedværker tilbage i henholdsvis 1910'erne og 1960/70'erne. Dette træder tydeligt frem i de to bedagede herrers syn på sådanne emner som; køn, social klasse og etnicitet.

I $\varnothing$ vrigt er der i tiden fra ca 1970 ligeledes kommet meget nyt frem takket være arkæologiske nyfund. I den forbindelse kan det nævnes, at en række forsøg på at slå bro mellem historievidenskaben og arkæologien er blevet søsat. Eksempelvis har englænderne Catherine Morgan og Anthony Snodgrass søgt at sammenkoble arkæologiske fund med historiske kilder for på den måde at opnå en $\emptyset$ get forståelse for samfundsforhold i tidsperioder, hvorom vi har et meget ringe antal historiske (d.v.s. skriftlige) udsagn.

Golden gør selv opmærksom på, at det er lidt af et paradoks, at ikke flere har forsøgt at sætte oldgrækernes fascination og intense beskæftigelse med fysisk aktivitet ind en større samtidig samfundsmæssig forståelsesramme. Det paradoksale bliver ikke af mindre omfang, når man tager i betragtning, at netop de sidste godt 15 år har budt på en gylden periode, hvad angår udforskningen af oldtidens idrætsliv.

Der kan således med god ret trækkes en streg ved David C. Young's debatskabende bog fra 1984 The Olympic Myth of Greek 
Amateur Athletics der jog en tyk pæl gennem forestillingen om det oldgræske amatør ideal. Young konstaterede, på baggrund af meget vidtgående kildestudier, at grækerne ganske enkelt ikke skelnede mellem professionel og amatør.

Efter Young gik det rask fremad med Donald G. Kyles værk Athletics in ancient Athens fra 1987 som det første centrale værk. Heri blev det for første (og indtil dato sidste) gang søgt at belyse og drage slutninger angående sportens rolle i én bestemt græsk bystat - Athen. Dette mikroperspektiv gav mulighed for en stærk sammenbinding af tre $» k l a s s i s k e$ « temaer - sport og religion, sport og krigsførelse samt sport og politik.

Disse tre perspektiver tager Mark Golden også op for derefter at brede perspektivet ud og inddrage sportens afgørende rolle i oldtiden som distinktions markør. Den oldgræske term agon er i denne sammenhæng allestedsnærværende. Agon, det almindelige ord for konkurrence, er at finde i det engelske agony, der betyder pine, smerte eller dødskamp. Hermed antydet, at sport og atletiske lege ofte var dødelig alvor for oldgrækerne. For dem var der i sidste instans kun én ting, som gjaldt - sejren over modstanderen (der så for de mest filosofisk anlagte godt kunne vise sig at være en selv).

\section{En amerikaners bud på vekselvirkningen mellem sport, kultur og religion}

Max Weber opfattes sammen med Émile Durkheim som grundlæggeren af den moderne sociologi. Af disse to er Webers forfatterskab vel nok det mest komplekse og ambitiøse. Bidragene til sociologien er enorme og vidtfavnende. Weber nåede i sit korte liv at udfærdige en filosofisk base gældende for socialvidenskaben som sådan og videre et begrebs- og teoretisk apparatur møntet mere specifikt på sociologien. Hertil blev lagt en række studier dækkende alle verdensreligionerne, oldtidens samfund, økonomisk historie, juraens og musikkens sociologi og mange flere.

Måske er det denne variation i såvel tema som metodisk-teoretisk perspektiv, der holder Weber evig ung - i den forstand, at han stadig har noget at sige videnskabsfolk anno år 2000. Mange er stadig de værker, der tilskriver tyskeren en stor del af æren for udformningen af det færdige produkt.

Et sådant er Steven J. Overmans bog fra 1997, der tager udgangspunkt i en konkret undren over, hvorfor (mange) nordamerikanere (i betydningen folk fra USA) tager deres sport og deres fritids-idræt så forfærdelig seriøs. Den lange titel på Overmans værk The Influence of the Protestant Ethics on Sport and Recreation (der i øvrigt står i et rimeligt forhold til udgivelsens volume) angiver klart og tydeligt, hvad det er for en del af Max Webers forfatterskab, der danner afsættet.

I starten af forrige århundrede udgav Weber sit siden så kendte værk om sammenhængen mellem den protestantiske (calvinistiske) etik og gennembruddet for den kapitalistiske $\varnothing$ konomi. Weber mente, at den protestantiske etik virkede som en generel kulturel kraft, der påvirkede en bred vifte af sociale praksisformer og institutioner langt udover de med direkte tilknytning til (markeds) økonomien. Denne pointe gør Overman til sin og sætter som grundlæggende præmis for sit arbejde, at den protestantiske etik har fået en afgørende indflydelse på en række kollektive og individuelle institutioner i Nordamerika. Hertil lægges en tese om, at der i kølvandet på, det Weber betegner det protestantiske 
arbejdskodeks, som er et centralt begrebsligt fikspunkt i teorien om den protestantiske etik, følger en protestantisk sport-ethos, der kommer til at sætte sit præg på nordamerikansk idræt, hvad angår såvel form og indhold som tilskrevne betydninger.

Overman's teser er spændende, og der er en masse godt at hente om sport og samfund i det Nordamerika, hvorfra vi importerer adskillelige trends tilknyttet sportsog kropsfeltet. Men forfatteren er flere gange selv, uden at vide det eller måske rettere uden at ville vide af det, inde på værkets største problem. Nemlig, at der søges gabt over ret så mange store emner. Nævnt i flæng; baggrunden for og konsekvenserne af den protestantiske revolution, sammenligning af den protestantiske og katolske kultur, kapitalisme og transformationen af amatør-idrætten samt børneopdragelse- og opvækst set i samfund præget af en protestantiske etik. Og så er der ikke en gang taget fat på problematikker mere specifikt rettet mod sportens felt.

Omfavnelsen i tid- og rum er ganske betragtelig. Dette leder til tider til en for simpel og ikke-detaljeret udlægning af det nordamerikanske samfund, dets sport og idræt. For sagen er selvfølgelig, at selvom der nok er en geografisk enhed som med nogen sikkerhed kan kaldes den nordamerikanske, så består denne af en lang række del-samfund - forstået som en gruppe af mennesker med en stærk fælles oplevelse af særlig kulturel, religiøs, etnisk og/eller anden social samhørighed - og de forsvinder i det perspektiv Overman betjener sig af, hvor alle groft sagt fremstår som hvide hårdtarbejdende middelklasse-personer med et udpræget Weber-protestantisk livssyn (uafhængigt af, hvilken religion de så i $\emptyset$ vrigt officielt måtte bekende sig til). Det ændrer imidlertid ikke ved, at der er tale om et originalt arbejde, der udover at være informativt på en lang række punkter ligeledes anfører en række mulige spændende tilgange til eksisterende eller kommende studier af idræt og sport i det (sen)moderne vesterlandske samfund.

\section{Den engelske sport som kultureksport}

Den moderne sport fandt som bekendt sin oprindelige form i Storbritannien hvorfra den i løbet af det 19. og 20. århundrede bredte sig til resten af verdenen. I flere lande har man interesseret sig for, hvorledes den engelske sport blev importeret, og hvilke konsekvenser det fik for den allerede eksisterende legemskultur. De specielle samfundsmæssige omstændigheder, der gjorde sig gældende i forbindelse med den engelske sports etablering i Tyskland, er genstand for Christiane Eisenbergs undersøgelse i habillitationsskriftet »English sports " und deutsche Bürger. Eine Gesellschaftsgeschichte 1800-1939 (1999). Da den engelske sport blev introduceret i Tyskland, eksisterede Turnbevægelsen allerede som den dominerende legemskultur, båret af især det borgerlige mellemlag. Det var det samme mellemlag, der med tiden tog den engelske sport til sig og forbandt den med Turnbevægelsen. På det samfundsmæssige plan fik især selve konkurrencemomentet i den engelske sport stor betydning, i og med dette førte til udbredelsen af den borgerlige-liberale ideologi i Tyskland, hvor de traditionelle bærere af denne ideologi, borgerskabet, ellers stod magtpolitisk svagt. Konkurrencemomentet i sporten fik i Tyskland således, efter Eisenbergs undersøgelse at dømme, betydning for grundfæstelsen af idéen om den økonomiske konkurrence om markedsandele. 
Kenya var ét sted, hvor den engelske sport blev introduceret som en del af den såkaldte »christian muscularity « som en opdragelsesform anvendt af det britiske imperiums missionærer, på samme måde som det skete i andre afrikanske lande og i Indien. Intet sted som i Kenya har etableringen af den engelske sports bevægelsesform imidlertid ført til fremkomsten af flere generationer af løbere, der med succes har vundet den ene medalje efter den anden. De kenyanske løbefænomener har selvfølgelig påkaldt sig idrætsforskernes interesse. Sidste år bragte årbogen en kritik af den i Storbritannien præmierede bog Kenyan running: Movement culture, geography and global change (1996) af John Bale og Joe Sang. Den ene af kritikerne Dirk Lund Christensen giver i bogen Washindi. Løberne fra Kenya (2000) i oversigtsform sit bud på, hvorfor lige netop Kenya producerer Washindi (vinderne). Vi får ikke et egentlig svar, men bliver helt godt oplyst, selv om fremstillingen indimellem er rigelig bredt anlagt.

Fremstillingen er delt i tre dele. Første del omhandler kalenjin-folkets land, historie, traditioner og kultur. Kalenjin-folket udgør 10 procent af Kenyas befolkning, men producerer 70 procent af landets topløbere. Anden del beskriver Kenyas overgang fra traditionelt samfund til kolonistyre og selvstændig nation med reference til idrætten, hvor et særligt kapitel vies til Kenyas hidtil største løber og atlet Kipchoge Keino. Tredie del diskuterer forskningens interesse for at kunne forstå det kenyanske løbefænomen. Der er tale om et etnisk fænomen, der langt fra er fuldt udforsket - vigtig er det i forhold til denne problematik ifølge forfatteren at undgå eventuelle racistiske undertoner og i stedet focuserer på selve fanomenet. Her som i så mange andre af livets sammen- hænge er svaret komplekst. Det kenyanske løbefænomen skyldes ikke én, men flere faktorer.

Det er ofte blevet hævdet, at sporten opfatter den menneskelige krop som en maskine eller som en motor, der driver mennesket fremad, hvorfor sporten på mange punkter betragtes som åndsforladt og uden hensyntagen til kroppens æstetiske dimension. At denne opfattelse ikke udelukkende er relateret til sporten fremgår af Jens Lunggrens tankevækkende dorktorafhandling Kroppens Bildning. Linggymnastikkens manlighetsprojekt 1790-1914 (1999). Afhandlingen, der udspringer af det idrætshistoriske seminar ved Stockholms Universitets historiske institut under ledelse af Jan Lindroth, påviser, hvorledes også opfattelsen af kroppen hos den mandlige gymnast $i$ Sverige i løbet af det 19. århundrede ændrede sig. I begyndelsen af 1800-tallet indeholdt det mandlige kropsideal i den lingske gymnastik såvel kraftfulde som æstetiske og idealistiske elementer. Ved begyndelsen af det 20. århundrede var det mandlige kropsideal i højere grad reduceret til at bestå af kraftfulde og krigeriske motoriske elementer. Mands-gymnastikken i Sverige blev således ført ud af Guds tempel og ind i det moderne samfund.

\section{Kongresser og seminarer}

I 1998 afholdtes i København the History of Sport in Europe sit tredie seminar. En række af de væsentligste indlæg på seminaret er i redigeret form blevet udgivet i publikationerne The History of Physical Education \& Sport from European Perspectives (1999) ved Arnd Krüger og Else Trangbæk samt Gender \& Sport from European Perspectives (1999) ved Else Trangbæk og Arnd Krüger. Publikationerne bringer os viden om »physical education« $i$ et såvel 
samfundsmæssigt og kønsmæssigt perspektiv som i mere snæver nationalstatslig eller disciplinorienteret forstand.

Det samfunds- og kønsmæssige perspektiv er ligeledes i højsædet i to længe ventede publikationer, der er udsprunget af seminarer arrangeret af ansatte ved Odense Universitet - nu Syddansk Universitet. Jørgen Povlsen, Signe Mellemgaard og Ning de Coninck-Smith har i bogen Childhood and Old Age. Equals or Opposites redigeret indlæggene fra et seminar med samme titel. Perspektivet er alder forstået som et samfundsmæssigt og historisk fænomen frem for et biologisk. Jørgen Povlsens bidrag »When Men are Made into Boys. Old Boys in the Danish Sports Movement - The Sporting Fellowship of Elderly Men in the Beginning of the $20^{\text {th }}$ Century« kaster lys over et $i$ idrætten hidtil uudforsket emne.

Den anden seminar-publikation Sports, Body and Health redigeret af Jørn Hansen og Niels Kayser Nielsen indholder artikler, der tager fat på relationerne krop, idræt og sundhed i en historisk og sociologisk kontekst. I relation til de to $k \emptyset n$ diskuteres idræt og sundhed i et historisk perspektiv ud fra, at idræt indlysene opfattedes som sundt for mænd, medens dette absolut ikke tidligere var tilfældet for kvinder.

\section{Jubilaeer}

Til sidst bør to enkeltstående jubilæumspublikationer omtales. Bent Aarre bruger den store pensel, når han i Lystsejlads i Danmark. Sejlsportens kulturhistorie 1855-1966 (1998) beretter om udviklingen på vandet. Irriterende nok er der ingen henvisninger til litteraturforlæg eller kilder. Til gengæld er der et rigt billedmateriale, der i sig selv fortæller mange historier. Selv om man som læser selvfølgelig altid bliver lidt oplyst, må undertitlen »Sejlsportens kulturhistorie« betegnes som lovlig ambitiøs, da skriftet ikke indeholder historiske analyser.

Samme problemstilling gør sig gældende for jubilæumsskriftet Dansk Bilsport $i$ 50 år. Historien om Dansk Automobil Sports Union 1948-1998 (1998) som Morten Alstrup er ansvarlig for. Også dette skrift indeholder mange gode informationer og billeder og vil kunne bibringe den ukyndige en viden om dansk bilsports historie i grove træk. Men også her mangler der historiske analyser samt henvisninger til litteraturoplæg og kilder. 